\title{
What Is Clean Cities?
}

Clean Cities is a government-industry partnership designed to reduce petroleum consumption in the transportation sector by advancing the use of alternative fuels and vehicles, idle reduction technologies, hybrid electric vehicles, fuel blends, and fuel economy measures.

Sponsored by the U.S. Department of Energy's (DOE) Vehicle Technologies Program (VTP), Clean Cities contributes to the energy, environmental, and economic security of the United States by supporting local decisions to reduce our dependence on imported petroleum. Established in 1993 in response to the Energy Policy Act (EPAct) of 1992, the partnership provides tools and resources for voluntary, community-centered programs to reduce consumption of petroleum-based fuels.

In almost 90 coalitions, government agencies and private companies voluntarily come together under the umbrella of Clean Cities. The partnership helps all parties identify mutual interests and meet the objectives of reducing the use of imported oil, developing regional economic opportunities, and improving air quality.

\section{Which technologies are included?}

The portfolio provides a range of options and flexibility to meet the petroleum reduction goals.

Clean Cities deploys technologies and practices developed by VTP. These include truck stop electrification and onboard auxiliary power to reduce fuel used in idling trucks, hybrid electric vehicles, the blending of nonpetroleum based fuels (such as ethanol or biodiesel) with conventional fuels, higher efficiency vehicles and driving practices, and the cornerstone of the portfolio, alternative fuels. The alternative fuels, which are defined by EPAct and supported by Clean Cities, include ethanol, biodiesel, hydrogen, electricity, liquefied petroleum gas (propane), and natural gas.

\section{How does Clean Cities work?}

\section{The partnership mobilizes local stakeholders in} government and industry.

Clean Cities draws stakeholders from local, state, and federal agencies; public health and transportation departments; commercial fleets; transit agencies; and other government offices; as well as auto manufacturers, car dealers, fuel and equipment suppliers, public utilities, and nonprofit associations. More than 5,500 stakeholders have accepted the invitation to contribute to the partnership's mission.

Clean Cities is instrumental in cultivating an advanced transportation community in which people learn about a wide range of options and technologies. In addition, Clean Cities helps create markets for alternative fuel vehicles (AFVs), hybrids, fuel blends, fuel economy, and idle reduction. A Clean Cities coalition can provide a forum for members to leverage their resources, develop joint projects, collaborate on public policy issues, and promote petroleum reduction and clean air technologies.

The partnership addresses the challenge of moving the United States away from the infrastructure and practices that contribute to dependence on imported petroleum and toward energy independence and security. In support of this challenge, Clean Cities assists the nation in meeting its objectives for renewable and alternative fuel use.

\section{What kind of assistance does Clean Cities offer? Clean Cities provides coordinated strategies and technical and funding resources.}

At the national level, Clean Cities provides original equipment manufacturers, trade associations, and other federal agencies with coordinated strategies and resources they can leverage to obtain maximum petroleum reduction. Clean Cities also provides coalitions with access to information and incentives from DOE and other federal agencies and industry partners that can help fund significant, high-impact projects.

Additionally, Clean Cities provides a large collection of technical data and information, including current data on fuels, vehicles, fueling station and truck-stop electrification locations, infrastructure development, state and federal incentives and laws, technical and outreach publications, and industry resources-all available online. Finally, Clean Cities offers technical assistance to coordinators as they work to develop infrastructure and market strategies. 


\section{Contacts}

Clean Cities staff members are available to assist you.

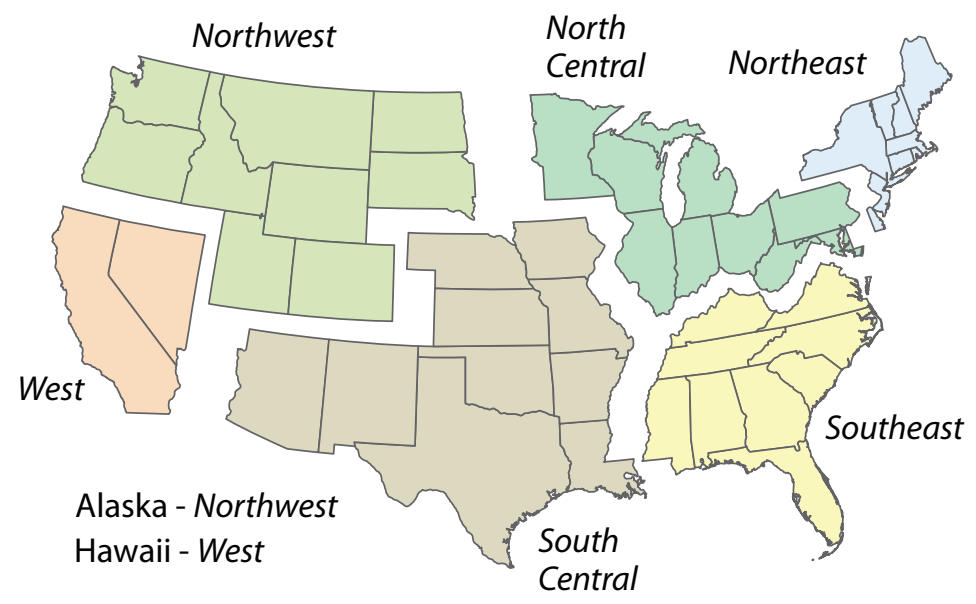

DOE Headquarters

Dennis A. Smith

Technology Deployment Manager and Clean Cities Director dennis.a.smith@ee.doe.gov 202-586-1791

DOE Regional Managers

Mike Scarpino

Northeast Region

michael.scarpino@netl.doe.gov

412-386-4726

Kay Kelly

North Central Region

kay.kelly@netl.doe.gov

304-285-4535

Steven Richardson

Southeast Region

steven.richardson@netl.doe.gov

304-285-4185
Linda Bluestein

Clean Cities Co-Director linda.bluestein@ee.doe.gov 202-586-6116
Neil Kirschner

South Central Region neil.kirschner@netl.doe.gov 412-386-5793

Ernie Oakes

Northwest Region

ernie.oakes@go.doe.gov

303-275-4817

Mike Bednarz

West Region

michael.bednarz@netl.doe.gov 412-386-4862

\section{Clean Cities Coordinators}

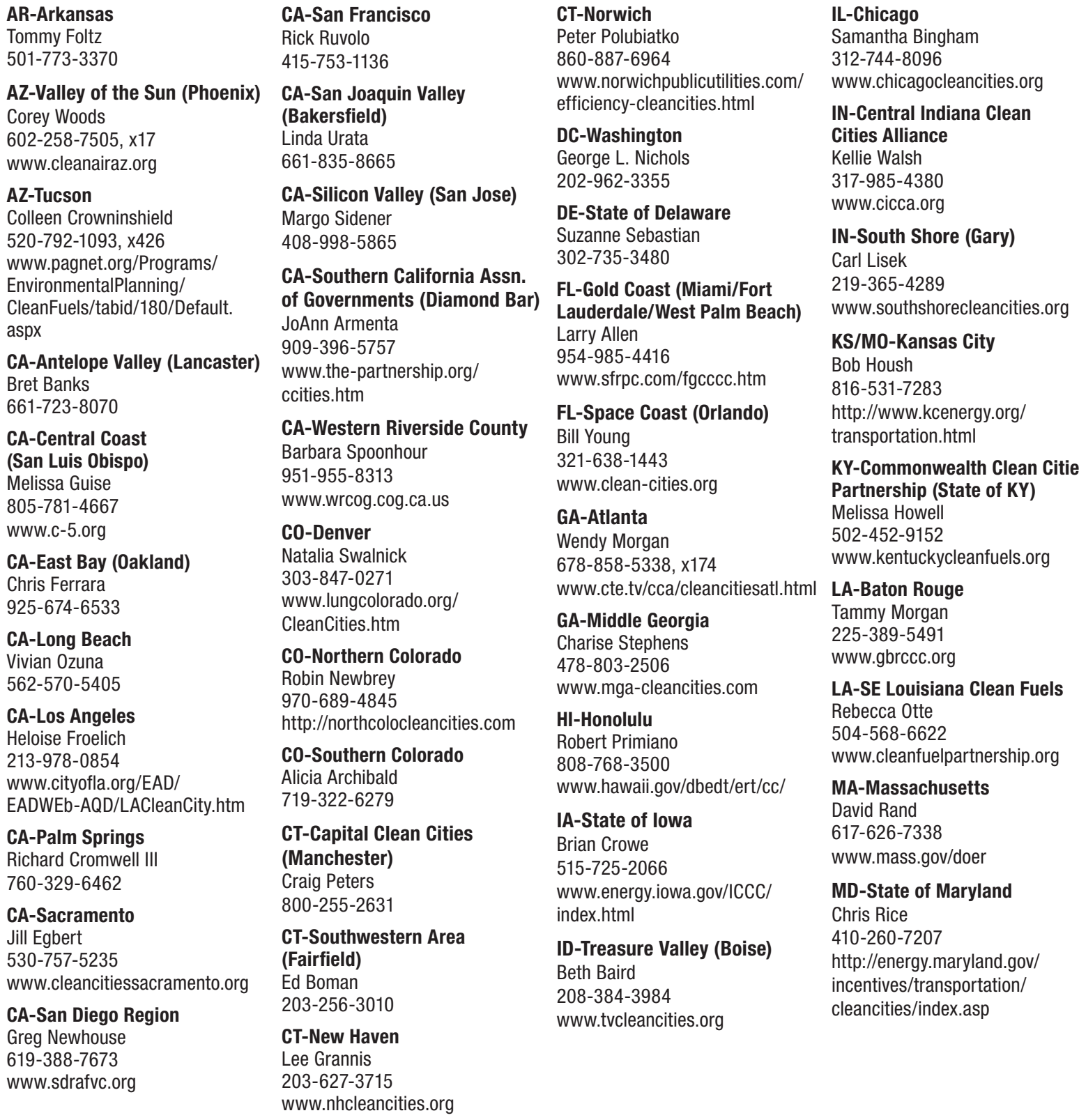

ME-Maine Clean Communities Steven Linnell 207-774-9891 www.gpcog.org/Transportation and_Land_Use/Maine_Clean Communities.php

MI-Ann Arbor

Sean Reed

888-818-0987

www.aacleancities.org

MI-Detroit

Dan Radomski

313-833-0100, x150

www.nextenergy.org/

industrygroups/clean_cities.asp

MI-Greater Lansing

Maggie Striz Calnin

517-290-2298

www.michigancleancities.org

MN-Twin Cities

Lisa Thurstin

651-223-9568

www.cleanairchoice.org/cities

MO-St. Louis

Kevin Herdler

314-822-5831

www.stlcleancities.org

NC-Centralina Council of Governments (Charlotte)

Jason Wager

704-348-2707

www.4cleanfuels.com

NC-Triangle Coalition (Raleigh Durham, Chapel Hill)

Kathy Boyer

919-558-9400

www.trianglecleancities.org

ND-Red River Valley (Grand Forks/Winnipeg, MB, Canada) Valerie Kummer 800-252-6325

www.cleanairchoice.org/cities/ rrv.cfm 


\section{Geographical Coverage of Clean Cities Coalitions}

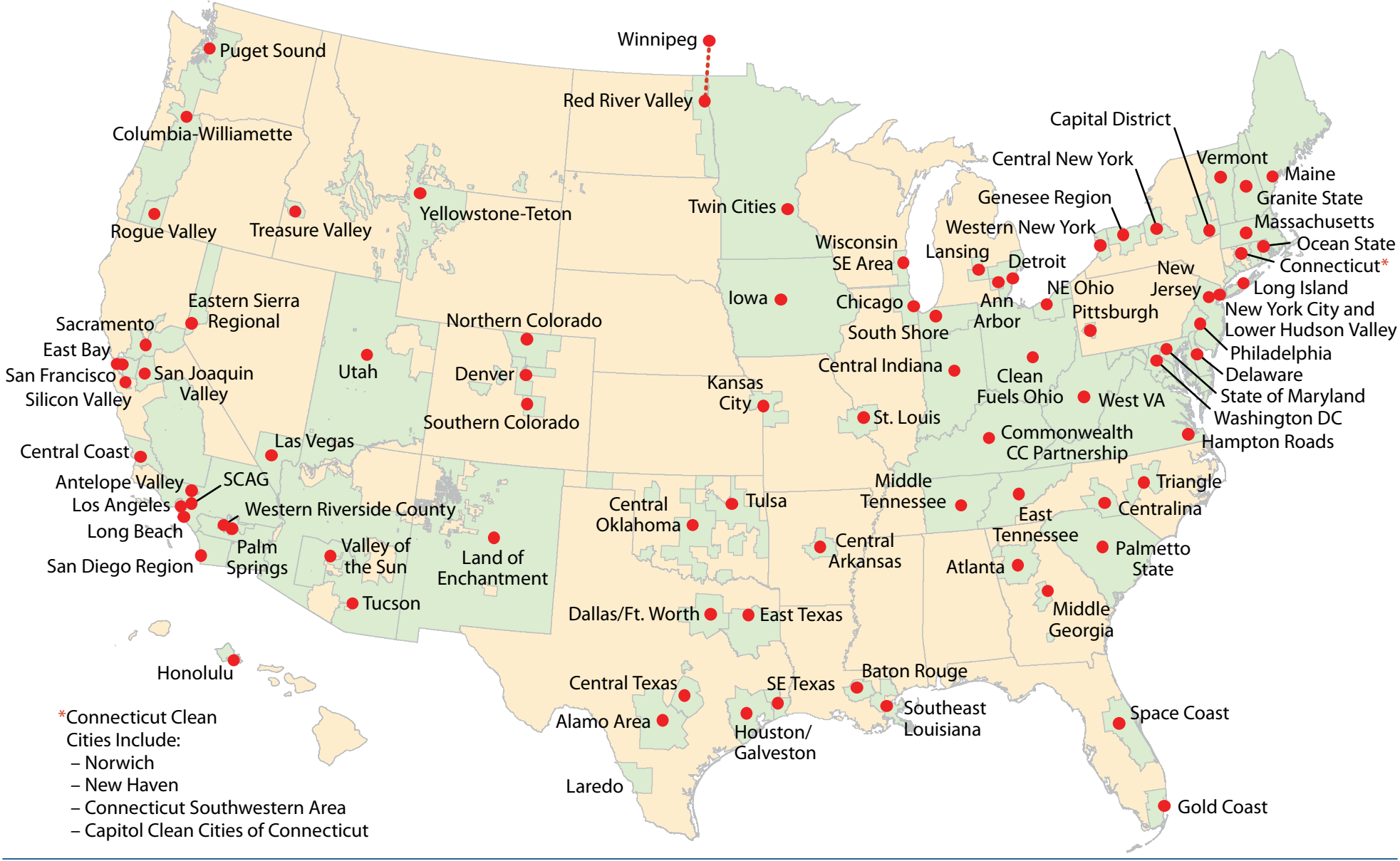

\section{NH-Granite State (State of NH)}

Barbara Bernstein

603-271-6751

www.granitestatecleancities.org

NJ-New Jersey

Ray Willer

908-380-1109

NM-Land of Enchantment

(Albuquerque)

Frank Burcham

505-856-8585

NV-Las Vegas

Dan Hyde

702-229-6971

www.lasvegascleancities.org

NV-Eastern Sierra Regional (Reno)

James Brandmueller

775-323-5879

NY-Capital District (Albany)

Deborah Stacey

518-458-2161

www.cdtcmpo.org/cdcc/cdcc.htm

NY-Central New York

(Syracuse)

Joseph Barry

315-498-2548

NY-Genesee Region (Rochester)

David Keefe

585-301-2433

www.grcc.us
NY-Long Island

Rita Ebert

631-969-3700 x25

www.gliccc.org

NY-New York City

Lou Calcagno

212-487-6820

NY-Western New York (Buffalo) Bill Pauly

716-435-5261

www.cleancommunitiesofwny.org

OH-Clean Fuels Ohio

(Columbus)

Sam Spofforth

614-884-7336

www.cleanfuelsohio.org

OH-Northeast Ohio (Cleveland)

John McGovern

216-281-6468 x223

http://www.earthdaycoalition.org/ cleanfuels/

OK-Central Oklahoma

(Oklahoma City)

Yvonne Anderson

405-234-2264

www.okcleancities.com

OK-Tulsa

Nancy Graham

918-584-7526

www.tulsacleancities.com
OR-Columbia-Willamette

(Salem)

Rick Wallace

503-378-3265

www.cwcleancities.org

OR-Rogue Valley (Medford)

Sue Kupillas

541-245-0770

PA-Philadelphia

Dennis Winters

215-790-1894

www.phillycleancities.org

PA-Pittsburgh

Ryan Walsh

412-241-9323

www.cleancities-pittsburgh.org

RI-Ocean State (State of RI)

Wendy Lucht

401-874-2792

http://www.uri.edu/cels/ceoc/

osccc.html

SC-Palmetto State (State of SC)

Erika Hartwig

803-737-7951

www.palmettocleanfuels.org

TN-East Tennessee (Knoxville) Jonathan G. Overly

865-974-3625

www.etcleanfuels.org
TN-Middle Tennessee

(Nashville)

Dave Pelton

615-482-4849

www.tennesseecleanfuels.org

TX-Alamo Area (San Antonio)

Andrew Hudgins

210-362-5228

www.aacog.com/cleancities/

default.asp

TX-Central Texas (Austin)

Stacy Neef

512-482-5343

www.ci.austin.tx.us/cleancities/

\section{TX-Dallas/Fort Worth}

Mindy Mize

817-608-2346

www.nctcog.org/trans/clean/

cities

TX-East Texas (Kilgore)

Rick McKnight

903-984-8641

www.netac.org/cities.htm

TX-Houston-Galveston

Christine M.B. Smith

832-681-2556

www.houston-cleancities.org

TX-South East Texas

(Beaumont)

Bob Dickinson

409-899-8444 x251

www.setccities.org
UT- Utah (Salt Lake City)

Robin Erickson

801-535-7736

www.utahcleancities.org

VA-Hampton Roads (Virginia)

Chelsea Jenkins

757-233-8982

www.hrccc.org

VT-State of Vermont

Karen Glitman

802-656-8868

www.uvm.edu/ cleancty

WA-Puget Sound (Seattle)

Mark Brady

206-689-4055

www.pugetsoundcleancities.org

WI-Southeast Area

(Milwaukee)

Francis X. Vogel

414-221-4958

www.wicleancities.org

WV-State of West Virginia

Kelly Bragg

800-982-3386, x2004

www.energywv.org

WY-Yellowstone-Teton

Sandy Shuptrine

307-733-6371

www.yellowstonetetonclean

energy.org

For the most current list of Clean Cities coordinators, visit www.eere.energy.gov/cleancities/progs/coordinators.php. 


\section{What has Clean Cities accomplished?}

Since 1993, Clean Cities and its stakeholders have reduced petroleum consumption by 2 billion gallons.

Clean Cities is integral to many success stories. It has spurred significant gains in the nation's AFV population and associated fueling infrastructure. Clean Cities tracks the activities and accomplishments of its coalitions, translating them into petroleum reduction. Clean Cities stakeholders annually submit data regarding alternative fuel-blend sales, AFV and hybrid electric vehicle deployment, idle reduction initiatives, and fuel economy measures. Clean Cities then analyzes the data to identify equivalent petroleum fuel reduction impacts. This tracking represents only a small percentage of the actual impact of Clean Cities. The program lays the groundwork for local and regional partnerships to increase the use of alternative and advanced vehicles and fuels, which ripples out from the coalitions.

Through local and national events, special emphasis is focused on educating fleet managers and interested stakeholders about Clean Cities technologies. In addition, Clean Cities has created many funding opportunities through a variety of financial support programs, making available millions of dollars and leveraging millions more in categories such as fuel infrastructure, AFV incremental cost buy-downs, and idle reduction education.

\section{Where can I find more information?}

Visit the following DOE Web sites to find programmatic information and technical data.

- Clean Cities: This site features program background and accomplishments, an online newsletter, and a toolbox (www.eere.energy.gov/cleancities).

- Alternative Fuels and Advanced Vehicles Data Center (AFDC): This comprehensive site provides detailed information on Clean Cities' five portfolio areas and has searchable databases of more than 3,000 documents and incentives and laws (www.eere.energy. gov/afdc). Also available on the AFDC:

- Vehicle Make/Model Search-Look up specs on alternative fuel and advanced technology vehicles and trucks and buses (www.eere.energy.gov/afdc/progs/ vehicles_search.php).

- Alternative Fueling Station Locator-Find fueling sites offering alternative fuels across the country (www.eere.energy.gov/afdc/fuels/stations_locator.html).

- FuelEconomy.gov: This site compares gas mileage, emissions, air pollution ratings, and safety data for new and used vehicles.

- EERE Information Center: This service provides assistance on energy efficiency and renewable energy topics. Inquiries requiring more technical expertise are forwarded to Clean Cities specialists (877-337-3463).
Cumulative Petroleum Fuel Equivalents Reduced

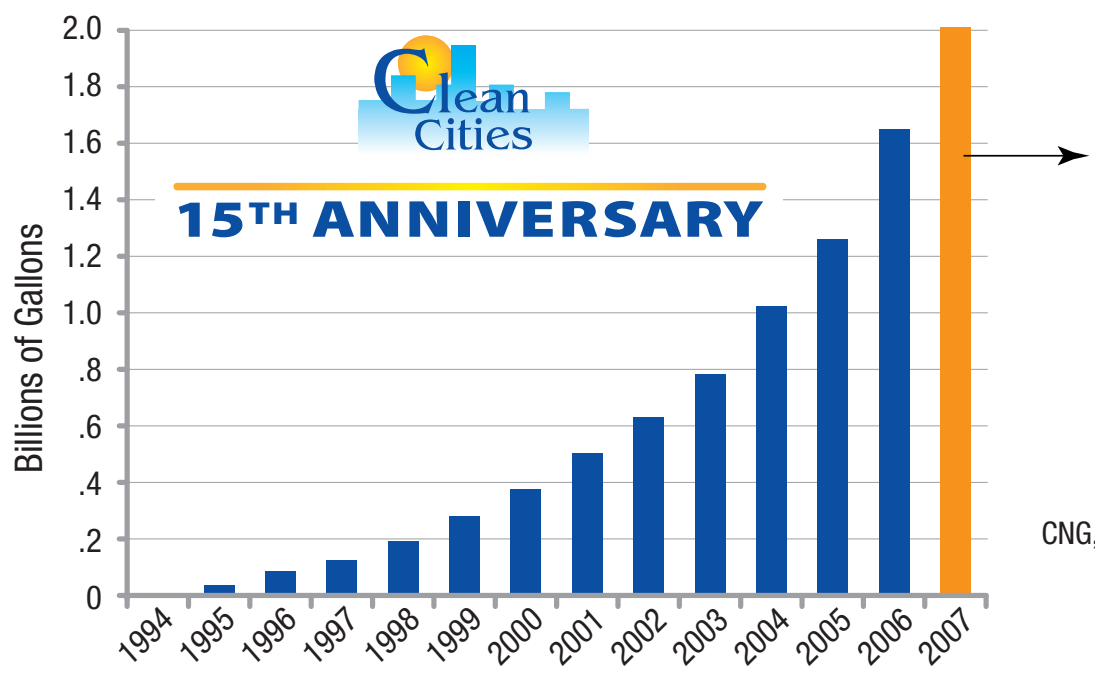

2007 Petroleum Reduction by Technology Type

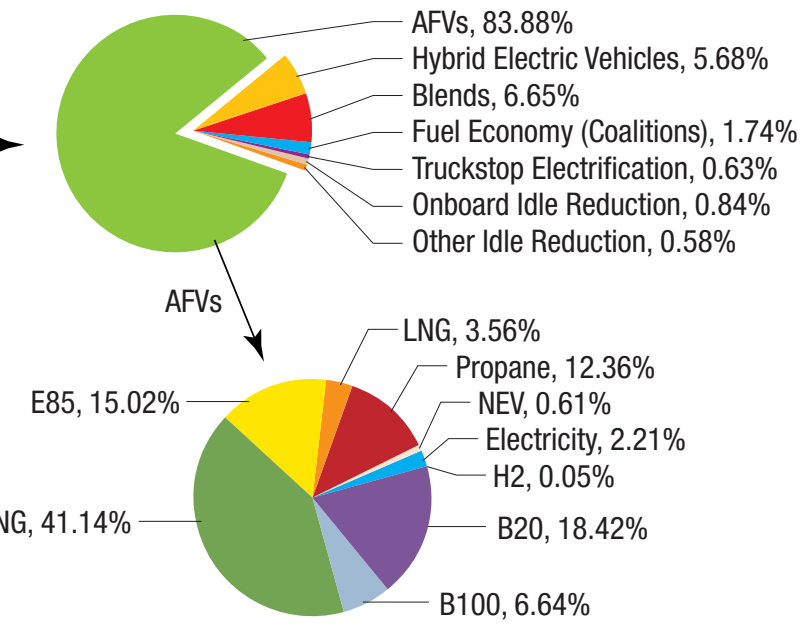

Breakdown of AFV Petroleum Reduction by Vehicle Type
Sponsored by the U.S. Department of Energy

Energy Efficiency and Renewable Energy

Vehicle Technologies Program

For more information contact: EERE Information Center 1-877-EERE-INF (1-877-337-3463)

www.eere.energy.gov

Prepared by the National Renewable Energy Laboratory (NREL)

NREL is a U.S. Department of Energy National Laboratory

Operated by Midwest Research Institute • Battelle
A Strong Energy Portfolio for a Strong America

Energy efficiency and clean, renewable energy will mean a stronger economy, a cleaner environment, and greater energy independence for America. Working with a wide array of state, community, industry, and university partners, the U.S. Department of Energy's Office of Energy Efficiency and Renewable Energy invests in a diverse portfolio of energy technologies.

DOE/GO-102008-2659 • September 2008

Printed with a renewable-source ink on paper containing at least 50\% wastepaper, including 10\% postconsumer waste. 